\title{
How Differences Between Fashion Innovators and Non- Innovators Among Young People?
}

\author{
Novika Candra Astuti ${ }^{*}$ \\ ${ }^{1}$ Widyatama University, Bandung, Indonesia
}

\begin{abstract}
Fashion is important for our life because not only it allows you to dress fashionably but also help connect with people of same interest and provides as a form of entertainment. These days' youth are becoming so obsessed with fashion and mainly follow trends to get a sense of identity that they waste most part of their time and money on fashion. The purpose of this study is to identify the difference between innovators and non-innovator among young people in adopting new fashion item influenced by the selected determinants i.e. information seeking, variety seeking, product evaluation, price sensitivity, and hedonic shopping. This research also investigates shopping behavior and attitude among young consumers. Total 121 questionnaires were distributed among undergraduate students in Bandung. The result shows that price sensitivity and hedonic shopping significantly differentiate between fashion innovators and non-innovators. The results of the study provide guidance to designers and entrepreneurs in the fashion industry that greater focused on innovative consumers.
\end{abstract}

Keywords: Fashion, Innovators, Non-Innovator, Young People

\section{INTRODUCTION}

Fashion can be defined as a form of freedom including not only clothing but also accessories, jewellery, bag, shoes, hairstyles, beauty and body art. Au, Taylor and Newton (2000) stated that fashion depicts a strong indicator of social identity, social class, self-image and the climate as what we wear and how and when we wear. The growth of the fashion world is like the movement of the earth's rotation around the sun. Shapes, styles, shades, colors, and creativity never stops and continues to evolve keep pace with the times. The fashion industry has many fans not only of young people but also adult classes both women and men. Any parent who has children also begins to notice the style and dress their children to follow the current fashion trends. These businesses have a large consumer attracting many business entrepreneurs and designers who compete in this industry. This can be seen by a growing number of shopping centers that provide variety of latest fashion, boutiques and fashion houses, and even many online businesses engaged in the field of fashion. Due to a change in the pattern of people's lives, they become more modern and consumptive of fashion products ready for use and practical.

The development of fashion in Indonesia both in style and production has been in transformation for more than a century. The fashion industry players in

\footnotetext{
* Corresponding author. Email address: novika.candra@widyatama.ac.id
} 
Indonesia have started doing business with the development holding commercial events at home and abroad intensive, such as trade event, retail exhibitions, trunk show and fashion show. Therefore, the fashion industry can increase the sale value of the trademark of product that necessarily can develop its business. Now, there are many fashion event performances on many occasions such as Indonesia fashion week, Indonesia Muslim Fashion Week, Kick Fest, Hijab Fest, etc. Participants come from local designers on board with national work that does not lose quality with foreign designers. They utilize domestic resource-rich Indonesian culture in every area such as songket, batik, woven, etc.

Bandung is one of cities in Indonesia known as a center of creative industries especially in fashion. Bandung has a lot of potential as a center of design and also the center of the fashion industry. The fashion industry has become one of the contributors to the high rate of economic growth in the city of Bandung, reaching $8 \%$ per year. Bandung is famous of variety of fashion facilities such as shopping centers from small to large scale, traditional and modern, and provides a wide range of latest fashion in accordance with market demand. The presence of several garment and textile industry in Bandung support fashion development. Besides that, Bandung is also supported by a number of educational facilities such as universities that focus on the fashion industry that become a gathering place for students, designers, fashionista, business entrepreneurs to discuss and exchange ideas.

The fashion industry is introducing new fashions every day. It's now a challenge for the fashion industry that, how they can successfully position their products in the minds of the consumers to excel profitably. Fashion adoption is focused on how consumers accept a prevailing style during a particular time. Fashion is accepted by the consumers and influences their behavior in many ways. This study is a step towards the better understanding of consumer behavior to adopt a new fashion. Consumer's adoption behavior regarding new product is a key point for the researchers. More understanding is required to predict adoption behavior, especially for the success of innovation. Managers who understand more about the innovators will be easier to communicate with them to persuade them to buy new products through smart marketing strategy. The information from this study will also add to our theoretical knowledge of innovators and their behavior, thereby improving this aspect of diffusion theory. This study tries to investigate the difference between innovators and non-innovator to adopt new fashion item influenced by the selected determinants i.e. information seeking, variety seeking, product evaluation, price sensitivity, and hedonism. This study also examines shopping behavior and attitude among young consumers.

\section{LITERATURE STUDY}

\section{Fashion as a domain specific of innovativeness}

Goldsmith \& Newell (1997) states that domain specific which means that consumers tend to be innovators for a specific product or product category. Fashion is one area that is found to be necessary in the diffusion of innovation, and the frequent introduction of new styles makes researchers' interest to study focusing 
on innovativeness (Goldsmith et al, 1998). Kaiser (1997:18) defines fashion as the process by which styles are introduced and accepted by consumers, and also to a particular style that is accepted by a large group of consumers at a particular time. Muzinich et al (2003) suggests that fashion is a socially valued or universal standard of taste that also incorporates the singularity and subjectivity of individual tastes. Fashion innovators are considered to help spread new fashion faster than others, so that by understanding this group should contribute to the development of new strategies to speed up adoption, and increase sales and profits. Given the evidence that innovativeness is domain specific, this study focused on fashion as the domain of interest. Therefore, fashion is seen as very relevant because of its symbolic properties and accessibility to most consumers.

\section{Innovativeness and Information Seeking}

Information seeking is defined as the activities that are brought out during looking for information. Rogers (2003) mentioned that an innovative person seeks information actively and has a greater exposure to different media sources. Because of greater information seeking, an innovator is more aware of the available information channel and maintains the quality of being an innovative individual. Innovation is the disposition of attitude able to persuade a person to seek information from the channels to raise awareness and involve some experimentation and risk-taking. Hirunyawipada and Paswan (2006) found that domain-specific innovativeness positively related with acquire information associating with new products.

\section{Innovativeness and Variety Seeking}

Kahn (1995) defined variety-seeking as "the tendency of individuals to seek diversity in their choices of services or goods". Variety-seeking tendency is rooted in need for a change in an attempt to resolve the boredom associated with a brand and a product (Van et al., 1996). Hoyer and Ridgway (1984) propose that personality traits are very essential for understanding variety seeking behavior. Variety seeking behavior is thought to have relevance for several areas of marketing; most work has been concentrated in the area of exploratory purchase behavior - i.e., brand switching and innovating behavior. One important outcome of the variety seeking drive in the context of consumer choice would be the desire for new or novel products manifested by purchase exploration (i.e., switching/innovating).

\section{Innovativeness and Product Evaluation}

When we buy a product whether we are aware of it or not, we go through a process of evaluation. Positive evaluation leads to acceptance and negative evaluation to rejection. Product characteristics have been an essential part of innovation adoption research for decades (Rogers, 1993; Goldsmith and Flynn, 1992; Goldenberg et al., 2001; Steenkamp and Gielsens, 2003). They are said to be crucial for consumer decision-making with respect to new products. Rogers (1993) categorized five characteristics of innovations, which significantly influenced the innovation-adoption process. These were: relative advantage, complexity, compatibility, trialability, and observability. The relative advantage of an innovation is the extent to which consumers in the target market perceive it to be 
superior in some important way to existing products. Compatibilty is the degree to which an innovation fits with the needs, values, and past experience of the consumer. Compatibilty has an important relationship with the lifestyle of an individual (Sääksjärvi, 2003). Complexity represents the extent of difficulty that an individual perceives to experience while using as well as understanding an innovation (Rogers, 2003). Observability is the degree to which the results of an innovative are visible to others. The easier it is for individuals to see the results of an innovation, the more likely they are adopt it (Rogers, 2003). Trialability is the degree to which an innovation may be experimented with on a limited basis.

\section{Innovativeness and Price Sensitivity}

Price sensitivity is an individual difference variable describing how individual consumers react to price levels and changes in price levels. A consumer high in price sensitivity will manifest much less demand as price goes up (or higher demand as price goes down), and consumers low in price sensitivity will not react as strongly to a price change (Goldsmith and Newell, 1997). Previous research has shown that innovators are relatively price insensitive, at least for new restaurant and fashionable clothing (Goldsmith, 1996; Goldsmith and Newell, 1997). While they are involved in getting good deals, this seems to be a result of their interest in the market place and not from price sensitivity per se. Innovators are more interested in acquiring the latest new product regardless of price owning to their involvement in the product category.

\section{Innovativeness and Hedonic Shopping}

Hedonic shopping value is more subjective and individualistic. Its value is perceived through fun and pleasure as opposed to goal achievement (Hirschman \& Holbrook, 1982). Also, hedonic shopping value reflects the pleasure and emotional worth of shopping (Bellenger et al., 1976). In the past, however, there was a considerable lack of papers examining hedonic shopping value compared to utilitarian shopping value (Sherry, 1990). Previous studies have identified and included fun, pleasure, recreation, freedom, fantasy, increased arousal, heightened involvement, new information, escape from reality, and others as hedonic shopping value (Darden \& Reynolds, 1971; Tauber, 1972; Hirschman \& Holbrook, 1982; Babin et al., 1994). Therefore, hedonic shopping value refers to the level of perception where shopping is considered emotionally useful through various positive feelings and worthwhile. Thus, hedonic shopping value can be understood as the emotional benefits the consumer perceives through the shopping experience other than the achievement of the original purchase intent (MacInnis \& Price, 1987). Westbrook and Black (1985) suggested that shopping enjoyment includes the opportunity for social interactions with friends, family or even strangers and the sensory stimulation such as escapisms from routine life, and new information about upcoming trends and fashion. Roehrich (1995) stated that innovativeness is an expression of two central needs; need for stimulation (Berlyne, 1960) and need for uniqueness (snyder and Fromkin, 1980). Consequently, his scale comprises two dimensions: hedonist innovativeness (tied to need for stimulation) and social innovativeness (tied to need for uniqueness). In this study, we use pleasure and 
gratification shopping, idea shopping, social shopping, role shopping, and value shopping to measure hedonic.

\section{HYPOTHESIS DEVELOPMENT}

In figure 1, researcher present a theoretical model based on previous research as discussed in literature review. Thus, the current study tried to understand differences consumer fashion innovativeness between innovators and noninnovators. The following hypotheses are formulated:

H1: There are significant differences of information seeking between innovators and non-innovators

$\mathrm{H} 2$ : There are significant differences of variety seeking between innovators and non-innovators

H3: There are significant differences of product evaluation between innovators and non-innovators

H4: There are significant differences of price sensitivity between innovators and non-innovators

H5: There are significant differences of hedonic shopping between innovators and non-innovators

H6: There are significant differences of shopping behavior between innovators and non-innovators

\section{RESEARCH METHODOLOGY}

\section{SAMPLE}

Researcher administered questionnaire to undergraduate students in Widyatama University, Bandung. Student sample is appropriate for convenience for testing such as this study, but the results cannot be generalized to larger populations (Calder et al., 1981). One hundred and twenty one students completed questionnaires. Table 1 shows respondent profile including fashion products purchased in the last 3/4 months, number of fashion items purchased in the last 12 months, and the average cost spent to purchase fashion products every month. The number of females and males are balance, $49.6 \%$ of male and $50.4 \%$ of female. The sample ranged in age between 18 to 20 years is $93.4 \%$. Seventy one point nine percent respondents have month allowance between $\mathrm{Rp} 1,000,100$ and $\mathrm{Rp}$ $2,000,000$. Clothing and shoes are fashion frequently bought by young consumer, constituting $32 \%$ and $29 \%$ respectively. Number of items purchased in the last 12 months is between $1-3$ items of $43.2 \%$ respondents and $20.3 \%$ respondents bought 4-5 items. Almost 26.7\% young consumers spent money between Rp 300.100 and Rp 500.000, 19.2\% spent between Rp 500.100 and Rp 700.00 and 19.2\% spent more than Rp 1.000.000 to buy fashion products.

Table 1 Respondent Profile

\begin{tabular}{llcc}
\hline Criteria & & Frequency & $\begin{array}{c}\text { Percentage } \\
(\boldsymbol{\%})\end{array}$ \\
\hline Gender & Male & 60 & 49.6 \\
& Female & 61 & 50.4 \\
\hline Age & $18-20$ years old & 113 & 93.4
\end{tabular}




\begin{tabular}{|c|c|c|c|}
\hline Criteria & & Frequency & $\begin{array}{c}\text { Percentage } \\
(\%)\end{array}$ \\
\hline & $21-23$ years old & 8 & 6.6 \\
\hline \multirow[t]{8}{*}{ Month allowance } & Rp 500.000 - Rp 1.000.000 & 17 & 14.0 \\
\hline & Rp 1.000.100 - Rp 1.500.000 & 49 & 40.5 \\
\hline & Rp 1.500.100 - Rp 2.000.000 & 38 & 31.4 \\
\hline & $\operatorname{Rp} 2.000 .100-\operatorname{Rp} 2.500 .000$ & 11 & 9.1 \\
\hline & $\operatorname{Rp} 2.500 .100-\operatorname{Rp} 3.000 .000$ & 3 & 2.5 \\
\hline & $\operatorname{Rp} 3.000 .100-\operatorname{Rp} 3.500 .000$ & 1 & 0.8 \\
\hline & $\operatorname{Rp} 3.500 .100-\operatorname{Rp} 4.000 .000$ & 2 & 1.7 \\
\hline & $>\mathrm{Rp} 4.000 .000$ & 0 & 0 \\
\hline \multirow{7}{*}{$\begin{array}{l}\text { Fashion products } \\
\text { purchased in the } \\
\text { last } 3 / 4 \text { months }\end{array}$} & Shoes & 74 & 29 \\
\hline & Slipper & 16 & 6 \\
\hline & Clothing & 81 & 32 \\
\hline & $\begin{array}{l}\text { Accessories (bracelets, } \\
\text { necklaces, rings, etc.) }\end{array}$ & 21 & 8 \\
\hline & Bag & 46 & 18 \\
\hline & Headscarf / veil & 11 & 4 \\
\hline & Others (shocks, jacket, etc) & 6 & 2 \\
\hline \multirow{5}{*}{$\begin{array}{l}\text { Number of fashion } \\
\text { items purchased in } \\
\text { the last } 12 \text { months }\end{array}$} & None & 2 & 1.7 \\
\hline & $1-3$ & 51 & 43.2 \\
\hline & $4-5$ & 24 & 20.3 \\
\hline & $5-7$ & 20 & 16.9 \\
\hline & $>7$ item & 21 & 17.8 \\
\hline \multirow{6}{*}{$\begin{array}{l}\text { The average cost } \\
\text { spent to purchase } \\
\text { fashion products } \\
\text { every month }\end{array}$} & $<\operatorname{Rp} 100.000$ & 4 & 3.3 \\
\hline & Rp 100.000 - Rp 300.000 & 21 & 17.5 \\
\hline & Rp $300.100-\operatorname{Rp} 500.000$ & 32 & 26.7 \\
\hline & Rp 500.100 - Rp 700.000 & 23 & 19.2 \\
\hline & $\mathrm{Rp} 700.100-\mathrm{Rp} 1.000 .000$ & 17 & 14.2 \\
\hline & $>\mathrm{Rp} 1.000 .000$ & 23 & 19.2 \\
\hline
\end{tabular}

\section{INSTRUMENT}

The measurement instrument consisted of a self completion questionnaire. The main body of the questionnaire is in the form of evaluation statements measuring the constructs identified from the relevant literature and the questionnaire mainly made use of by 5 -point Likert scale that ranges from $(1=$ Strongly Disagree, 2 = Disagree, $3=$ Neutral, $4=$ Agree to $5=$ Strongly Agree). Five established scales were used to to measure the different constructs. The Domain Specific Innovativeness Scale (DSI) was used to measure fashion innovativeness (Goldsmith et. al., 1998); Information Seeking scale to measure activities to look for information of fashion (Raju, 1980); Variety seeking scale to measure variety in fashion products choices (Kahn, 1995); revised Product Evaluation scale to measure evaluation of fashion product (Focus Group Discussion and Breivik et al. (1998)); Hedonic shopping scale to measure hedonism of consumer toward fashion including pleasure and gratification shopping, idea shopping, social shopping, role shopping, and value shopping (Arnold and Reynolds, 2003). 


\section{RESULTS}

\section{Scale Reliability}

The data were encoded numerically in MS Excel and statistically analysed and computed in SPSS 16.0. The reliability was calculated using Cronbach's coefficient alpha recommended to be accepted by Nunnally (1978) that is between 0.50 and 0.70 . However, we achieved the normality and reliability of the data with the values of Cronbach's alphas as shown in the table 2.

Table 2 Scale Reliability

\begin{tabular}{|c|c|c|c|c|}
\hline \multicolumn{2}{|c|}{ Variable } & \multirow{2}{*}{$\begin{array}{l}\text { Scale Items } \\
\text { When I hear about a new store, } \\
\text { I am keen on finding out more } \\
\text { about. }\end{array}$} & \multirow{2}{*}{$\begin{array}{c}\text { Alpha if } \\
\text { deleted }\end{array}$} & \multirow{2}{*}{$\begin{array}{c}\text { Reliability } \\
0.749\end{array}$} \\
\hline $\begin{array}{c}\text { Information } \\
\text { Seeking }\end{array}$ & IS1 & & & \\
\hline & IS2 & $\begin{array}{l}\text { I often look through } \\
\text { catalogues even I am not } \\
\text { planning to order anything. }\end{array}$ & 0.782 & \\
\hline & IS4 & $\begin{array}{l}\text { I like testing free product } \\
\text { samples of different brands } \\
\text { because it enables me to } \\
\text { compare. }\end{array}$ & 0.668 & \\
\hline & IS5 & $\begin{array}{l}\text { I often read advertisements } \\
\text { just out of curiosity. }\end{array}$ & 0.658 & \\
\hline & IS6 & $\begin{array}{l}\text { If I see a new brand that seems } \\
\text { to be somewhat to the one I } \\
\text { usually buy, I am keen finding } \\
\text { out more about it. }\end{array}$ & 0.596 & \\
\hline & IS7 & $\begin{array}{l}\text { I rarely read advertisements } \\
\text { that just seem to contain a lot } \\
\text { of information. }\end{array}$ & 0.559 & \\
\hline & IS8 & $\begin{array}{l}\text { Sometimes I amble through } \\
\text { stores with curiosity without } \\
\text { planning to buy anything. }\end{array}$ & 0.754 & \\
\hline \multirow[t]{5}{*}{$\begin{array}{l}\text { Variety } \\
\text { Seeking }\end{array}$} & VS1 & $\begin{array}{l}\text { I think it is boring to always } \\
\text { buy the same brands even if } \\
\text { they are good. }\end{array}$ & 0.874 & 0.613 \\
\hline & VS4 & $\begin{array}{l}\text { I enjoy exploring several } \\
\text { different alternatives or brands } \\
\text { when shopping. }\end{array}$ & 0.520 & \\
\hline & VS5 & $\begin{array}{l}\text { To not always buy the same } \\
\text { brands, I shop among a few } \\
\text { different brands. }\end{array}$ & 0.839 & \\
\hline & VS6 & $\begin{array}{l}\text { There are many products, } \\
\text { where I always switch among } \\
\text { few brands. }\end{array}$ & 0.738 & \\
\hline & VS7 & $\begin{array}{l}\text { When old thing gets boring, I } \\
\text { like to find some new styles } \\
\text { and products. }\end{array}$ & 0.759 & \\
\hline
\end{tabular}




\begin{tabular}{|c|c|c|c|c|}
\hline \multicolumn{2}{|c|}{ Variable } & \multirow{2}{*}{\begin{tabular}{l}
\multicolumn{1}{c}{ Scale Items } \\
$\begin{array}{l}\text { I evaluate products based on } \\
\text { quality }\end{array}$
\end{tabular}} & \multirow{2}{*}{$\begin{array}{c}\text { Alpha if } \\
\text { deleted }\end{array}$} & \multirow{2}{*}{$\begin{array}{c}\text { Reliability } \\
0.713\end{array}$} \\
\hline $\begin{array}{c}\text { Product } \\
\text { Evaluation }\end{array}$ & PE1 & & & \\
\hline & PE2 & $\begin{array}{l}\text { When I consider buying } \\
\text { something I ask other people } \\
\text { around me for advice. }\end{array}$ & 0.866 & \\
\hline & PE3 & $\begin{array}{l}\text { When choosing something, } \\
\text { other people's opinion is } \\
\text { important to me. }\end{array}$ & 0.868 & \\
\hline & PE4 & $\begin{array}{l}\text { I evaluate the products based } \\
\text { on uniqueness / different from } \\
\text { other people have }\end{array}$ & 0.618 & \\
\hline & PE5 & $\begin{array}{l}\text { I need long time to evaluate } \\
\text { product }\end{array}$ & 0.705 & \\
\hline & PE6 & $\begin{array}{l}\text { I choose product that reflect } \\
\text { my lifestyle }\end{array}$ & 0.800 & \\
\hline & PE7 & $\begin{array}{l}\text { I usually think more deeply } \\
\text { when choose products that are } \\
\text { at high-risk than low-risk. }\end{array}$ & 0.623 & \\
\hline & PE8 & $\begin{array}{l}\text { It is very difficult to } \\
\text { discriminate between different } \\
\text { items when I need one }\end{array}$ & 0.850 & \\
\hline \multirow[t]{4}{*}{$\begin{array}{c}\text { Price } \\
\text { Sensitivity }\end{array}$} & PS1 & $\begin{array}{l}\text { I know that a new kind of } \\
\text { product is likely to be more } \\
\text { expensive than older ones, but } \\
\text { does not matter to me. }\end{array}$ & 0.858 & 0.550 \\
\hline & PS2 & $\begin{array}{l}\text { I do not mind paying more to } \\
\text { try out a new product. }\end{array}$ & 0.817 & \\
\hline & PS3 & $\begin{array}{l}\text { A really great product is } \\
\text { worth paying a lot of money } \\
\text { for }\end{array}$ & 0.870 & \\
\hline & PS4 & $\begin{array}{l}\text { I do not mind spending a lot of } \\
\text { money to buy a product }\end{array}$ & 0.889 & \\
\hline \multirow[t]{6}{*}{$\begin{array}{l}\text { Hedonic } \\
\text { Shopping }\end{array}$} & HE1 & $\begin{array}{l}\text { To me, shopping is an } \\
\text { adventure. }\end{array}$ & 0.628 & 0.850 \\
\hline & HE2 & I find shopping stimulating. & 0.833 & \\
\hline & HE3 & $\begin{array}{l}\text { Shopping makes me feel like I } \\
\text { am in my own universe. }\end{array}$ & 0.700 & \\
\hline & HE4 & $\begin{array}{l}\text { When I am in a down mood, I } \\
\text { go shopping to make me feel } \\
\text { better. }\end{array}$ & 0.896 & \\
\hline & HE5 & $\begin{array}{l}\text { To me, shopping is a way to } \\
\text { relieve stress. }\end{array}$ & 0.882 & \\
\hline & HE6 & $\begin{array}{l}\text { I go shopping when I want to } \\
\text { treat myself to something } \\
\text { special. }\end{array}$ & 0.798 & \\
\hline
\end{tabular}




\begin{tabular}{|c|c|c|c|c|}
\hline \multicolumn{2}{|c|}{ Variable } & Scale Items & \multirow{2}{*}{$\begin{array}{c}\begin{array}{c}\text { Alpha if } \\
\text { deleted }\end{array} \\
0.865\end{array}$} & \multirow[t]{2}{*}{ Reliability } \\
\hline & HE7 & $\begin{array}{l}\text { I go shopping to keep up with } \\
\text { the trends. }\end{array}$ & & \\
\hline & HE8 & $\begin{array}{l}\text { I go shopping to keep up with } \\
\text { the fashion. }\end{array}$ & 0.782 & \\
\hline & HE9 & $\begin{array}{l}\text { I go shopping to see what new } \\
\text { products are available. }\end{array}$ & 0.832 & \\
\hline & HE10 & $\begin{array}{l}\text { I enjoy socializing with others } \\
\text { when I shop. }\end{array}$ & 0.834 & \\
\hline & HE11 & $\begin{array}{l}\text { I go shopping with my friends } \\
\text { or family to socialize. }\end{array}$ & 0.777 & \\
\hline & HE12 & $\begin{array}{l}\text { Shopping with others is a } \\
\text { bonding experience. }\end{array}$ & 0.860 & \\
\hline & HE14 & $\begin{array}{l}\text { I enjoy shopping around to } \\
\text { find the perfect gift for } \\
\text { someone. }\end{array}$ & 0.869 & \\
\hline \multirow[t]{5}{*}{$\begin{array}{c}\text { Fashion } \\
\text { Innovativeness }\end{array}$} & FI1 & $\begin{array}{l}\text { In general, I am among the last } \\
\text { in my circle of friends to buy } \\
\text { fashion when it appears. }\end{array}$ & 0.862 & 0.660 \\
\hline & FI2 & $\begin{array}{l}\text { If I heard that a new fashion } \\
\text { was available in the store, I } \\
\text { would be interested enough to } \\
\text { buy it. }\end{array}$ & 0.817 & \\
\hline & FI3 & $\begin{array}{l}\text { I will not buy a new fashion } \\
\text { product if I haven't heard/tried } \\
\text { it yet. }\end{array}$ & 0.747 & \\
\hline & FI4 & $\begin{array}{l}\text { In general, I am the first in my } \\
\text { circle of friends to know the } \\
\text { brands of the latest consumer } \\
\text { fashion. }\end{array}$ & 0.817 & \\
\hline & FI5 & $\begin{array}{l}\text { I do not like to buy fashion } \\
\text { before other people do. }\end{array}$ & 0.650 & \\
\hline
\end{tabular}

\section{THE EXAMINATION OF THE INNOVATIVENESS SCALE AND} IDENTIFICATION OF ADOPTER GROUPS FOR FASHION PRODUCTS

Consumer innovativeness scale developed by Goldsmith and Hofacker (1991) consists of six statements and is a balanced scale. In this study, we found that only five items of fashion innovativeness are valid. The summed the scores given to each item to obtain an innovativeness score for each observation as suggested in both the study of Goldsmith and Hofacker (1991) and the study of Goldsmith and Flynn (1992). Summer scores on the innovativeness scale ranged from 8 to 29, with a mean of $20.25(\mathrm{sd}=2.79)$ and a median of 20 . For the purposes of the analysis, researcher split the distribution of innovativeness scores to form two groups of consumers, considering the standard deviation and the mean value using the same procedure followed in the study of Goldsmith and Flynn (1992). In this study, one standard deviation above the mean value for the innovativeness score was taken as a splitting point to form two groups of consumers. Thus 16 respondents, the top 
13.2 per cent of the sample distribution (those with scores 21 and above) were determined as innovators or early adopters. The remaining 105 individuals (86.8) were defined as non-innovators. The result of independent sample t-test analysis shows that the non-innovator group has significantly lower scores than the innovators. The evaluation also gives evidence the consistency of the method of segment between the innovators and non-innovators.

\section{FASHION INNOVATIVENESS AND PERSONALITY TRAITS (IS, VS, PE, PS, HE)}

The study aims to examine whether innovators and non-innovators differ significantly in information seeking, variety seeking, product evaluation, price sensitivity, and hedonic. Table 3 shows that results differences between innovators and non-innovators in those variables. Price sensitivity and hedonic were found to be significantly different from early and late adopters ( $\operatorname{sig}<0.05$ ). On the other sides, the significance value of information seeking, variety seeking, and product evaluation are more than 0.05 ; mean that there are no differences between these variables. We can conclude that we can reject H1, H2, H3 but accept $\mathrm{H} 4$ and H5. This study support previous research showing that innovators are relatively price insensitive in fashionable clothing (Goldsmith and Newell, 1997). Price has a significance influence on young consumers' purchase behavior toward fashion products. Non-innovators are sensitive toward price but innovators do not react as strongly to a price change. Consumers scoring high on hedonic shopping style are likely to obtain excitement and pleasure from seeking out new things through shopping. Goldsmith (1983) stated that consumers who pursue gratification in venturesome and exciting behaviors are more likely to purchase new products. Innovators tend to be consumers with the "recreational and hedonistic shopping consciousness" style possess the trait to find fashion shopping pleasant, and shop just for the fun of it and they consider shopping for recreation and entertainment compared to non-innovators.

Table 3 Innovativeness and Personality Traits

\begin{tabular}{|c|c|c|c|c|}
\hline \multirow[b]{2}{*}{$\begin{array}{c}\text { Personality } \\
\text { Traits }\end{array}$} & \multicolumn{2}{|c|}{ Mean Scores } & \multirow[b]{2}{*}{$\mathbf{t}$} & \multirow[b]{2}{*}{ Significance } \\
\hline & Innovators & $\begin{array}{c}\text { Non- } \\
\text { Innovators }\end{array}$ & & \\
\hline $\begin{array}{l}\text { Information } \\
\text { seeking }\end{array}$ & 30.154 & 29.561 & 0.523 & 0.602 \\
\hline Variety seeking & 18.455 & 17.722 & 0.922 & 0.358 \\
\hline $\begin{array}{l}\text { Product } \\
\text { Evaluation }\end{array}$ & 36.723 & 36.387 & 0.285 & 0.776 \\
\hline Price sensitivity & 15.455 & 13.170 & 3.599 & 0.001 \\
\hline Hedonic & 54.657 & 47.843 & 3.583 & 0.000 \\
\hline
\end{tabular}

\section{FASHION INNOVATIVENESS AND SHOPPING BEHAVIOR}

One of the purposes of this study is to analyze whether innovators and noninnovators differ significantly in their shopping habits or not. This study found contrast finding that there are no differences of shopping behavior between innovators and later adopters. Table 4 shows that there are no differences between innovators and non-innovators in shopping behavior (sig. values > 0.05). Therefore we can conclude that we reject H6. 
Table 4 Innovativeness and Fashion Behavior

\begin{tabular}{lcccc}
\hline \multicolumn{1}{c}{ Shopping Behavior } & Innovators & $\begin{array}{c}\text { Non- } \\
\text { Innovators }\end{array}$ & t & Significance \\
\hline $\begin{array}{l}\text { Number of fashion items } \\
\text { purchased in the last 12 }\end{array}$ & 2.625 & 3.019 & -1.175 & 0.242 \\
$\begin{array}{l}\text { months } \\
\begin{array}{l}\text { The average cost spent to } \\
\text { purchase fashion products } \\
\text { every month }\end{array}\end{array}$ & 4.375 & 3.629 & 1.781 & 0.077 \\
\hline
\end{tabular}

\section{SUMMARY}

This research is an attempt to evaluate and illustrate the value of the innovativeness scale developed by Goldsmith and Hofacker (1991) to identify differences between innovators and non-innovators for a specific product category - fashion product. The present study shows the use of a simple self-report scale to measure consumer innovativeness validly and reliably among young consumers within a specific product field. In this study, the researcher used the innovativeness scale to classify individuals into innovator and non-innovator groups.

This study, the variables of price sensitivity and hedonic shopping are found to be significant variables in profiling innovators. This research is not consistent with previous research (Uray and Dedeoglu, 1997) that shopping attitude/behavior related variables were also significant in distinguishing one group of another. This study enriches knowledge about fashion innovativeness that there are no differences between early and late majority in information seeking, variety seeking, and product evaluation. Young consumers both innovator and non-innovator have similar personality in looking for information for example "when I hear about a new store, I am keen on finding out more about", "I often look through catalogues even I am not planning to order anything", "when I hear about a new store, I am keen on finding out more about". Then, the tendency of young consumers to look for variety in their choices of fashion is found to be similar between two groups. They also have similar personality when they go through a process of evaluation.

Thus, the findings of this study indicate that not only demographic profile (i.e. sex, age and month allowance), but also shopping behavior related characteristics such as type of fashion products purchased in the last 3 or 4 months, number of fashion items purchased in the last 12 months, and the average cost spent to purchase fashion products every month. Although this study is not a complete place of the characteristics of the fashion innovator, the results of this study can be useful for each fashion designer and retailer to identify, profile fashion innovators and determine marketing program plan and policies accordingly.

\section{LIMITATIONS AND FUTURE RESEARCH}

It is important to note that the results of this study cannot be generalized to all young consumers. The future research should not only use students for respondents but also research adults to identify fashion innovators that adults who have own income can be investigated more deeply in identifying innovativeness in fashion. 
The probability sampling could be used the next research to avoid bias of the sample choice. Research in one of cities from Indonesia, Bandung, could not represent innovativeness among young consumers in fashion so that the next research should use sample from different cities that can be more valid to depict differences between young innovators and non-innovators in fashion industry. In order to compare the early buyers, three groups such as innovators, early adopters, and early majority should be examined rather than only early adopter and late majority. Future research should extend the approach of profiling fashion innovators systematically. In this today society, fashion products have important economic and social significance and should be a focus of many more studies.

\section{References}

Arnold, M.J., \& Reynolds, K.E. (2003). Hedonic shopping motivations. Journal of Retailing, 79, 77-95.

Au, J.S.C., Taylor, G., \& Newton, E.W. (2000). East and West think differently? The European and Japanese fashion designers. Journal of Fashion Marketing and Management, 4(3).

Babin, B., Darden, W.R., \&d Griffin, M. (1994). Work And/Or Fun: Measuring Hedonic And Utilitarian Shopping Value. Journal of Consumer Research, 20, 644-655.

Berlyne, D.E. (1960). Conflict, Arousal, and Curiosity. New York: McGraw-Hill.

Breivik, E., Troye, S.V., \& Olsson, U.H. (1998). Dimensions of Intangibility and Their Impact on Product Evaluation. Working Paper Presented to the Annual Conference. Association for Consumer Research.

Bellenger D.N., Steinberg, E., \& Stanton WW. (1976). The Congruence of Store Image and Self Image. J. Retail, 52(1), 17-32.

Calder, B.J., Phillips, L.W., \& Tybout, A.M. (1981). Designing Research for Application. Journal of Consumer Research, 8(2), 197-207.

Darden, W.R. \& Reynolds, F.D. (1972). Predicting Opinion Leadership For Men's Apparel Fashions. Journal of Marketing Research, 9(August), 324-328.

Goldenberg J., Libai B., \& Muller E. (2001). Riding the Saddle: How Cross-Market Communication Creates a Major Slump in Sales. Working Paper, Tel-Aviv $U$.

Goldsmith, R.E. (1983). Psychographics and New Product Adoption: An Exploratory Study. Perceptual and Motor Skills, 57(December), 1071-1076.

Goldsmith, R.E., \& Hofacker, C.F. (1991). Measuring Consumer Innovativeness. Journal of the Academy of Marketing Science, 19(3), 209-21.

Goldsmith, R.E., \& Newell, S.J. (1997). Innovativeness and Price Sensitivity: Managerial, Theoretical and Methodological Issues. Journal of Product and Brand Management, 6(3), 163-174.

Goldsmith, R.E., d' Hauteville, F., \& Flynn, L.R. (1998). Theory and Measurement of Consumer Innovativeness. European Journal of Marketing, 32, 340-353.

Goldsmith, R.E., \& Flynn, L.R. (1992). Identifying Innovators in Consumer Product Markets. European Journal of Marketing, 26(1)2, 42-55.

Hirunyawipada, T., \& Audhesh, K.P. (2006). Consumer Innovativeness and Perceived Risk: Implications For High Technology Product Adoption. Journal of Consumer Marketing. 
Hirschman, E.C., \& Holbrook, M.B. (1982). Hedonic consumption: Emerging Concepts, Methods and Propositions. Journal of Marketing, 46(Summer), 92-101. Hoyer, W.D., \& Nancy, M.R. (1984). Variety Seeking as an Explanation for Exploratory Behavior: A Theoretical Model. Advances in Consumer Research, (11ed).

Hoyer, W.D., \& Maclnnis, D.J. (2007). Consumer Behavior (4th ed.). Boston, NY: Houghton Mufflin.

Kahn, B.E. (1995). Consumer Variety-Seeking among Goods and Services. Journal of Retailing and Consumer Services, 2 (Fall), 139-148.

Kaiser, S. (1997). The Social Psychology of Clothing, (2nd ed). New York: Fairchild.

MacInnis, D., \& Price, L. (1987). The Role of Imagery in Information Processing: Review and Extensions. Journal of Consumer Research, 13 (March), 473491.

Muzinich, N., Pecotich, A., \& Putrevu, S. (2003). A model of the antecedents and consequents of female fashion innovativeness. Journal of Retailing and Consumer Services, 10, 297-310.

Nunnally, J. (1978). Psychometric Theory (2nd ed). New York: McGraw-Hill.

Rogers, E.M. (1993). Diffusion of Innovations. New York: The Free Press, pp. 55.

Rogers, E. M. (2003). Diffusion of Innovation (5th ed.). New York: The Free Press.

Saaksjarvi, M. (2003). Consumer Adoption of Technological Innovations. European Journal of Innovation Management, 6(2), 90-100.

Steenkamp, J. B., \& Gielsen, K. (2003). Consumer and Market Drivers of The Trial Rate of New Consumer Products. Journal of Consumer Research, 30, 368384.

Sherry, J.F. (1990). A Sociocultural Analysis of a Midwestern American Flea Market. Journal of Consumer Research, 17(1), 13-30.

Snyder, C.R., \& Fromkin, H.L. (1980). Uniqueness: The Human Pursuit of Difference. New York: Plenum.

Raju, P.S. (1980). Optimum Stimulation Level: Its Relationship to Personality, Demographics and Exploratory Behavior. Journal of Consumer Research, 7, 272-282.

Roehrich, G. (1995). Innovativite's he'doniste et sociale: proposition d'une e'chelle de mesure. Rech Appl Mark, 9(2), 19-41.

Tauber, E.M. (1972). Why Do People Shop?. Journal of Marketing, 36, 46-49

Thomas, C.K, Provo, UT: Association for Consumer Research, 114-119.

Uray, N., \& Dedeoglu, A. (1997). Identifying Fashion Clothing Innovators by SelfReport Method. Journal of Euromarketing, 6(3), 27-46.

Westbrook, R.A., \& Black, W.C. (1985). A Motivation-Based Shopper Typology. Journal of Retailing, 61(Spring), 78-103.

Van T.H., Hoyer, W., \& Inman, J. (1996). Why Switch? Product Category-Level Explanations For True Variety-Seeking Behavior. Journal of Marketing Research (JMR), 33(3), 281-292. 